\title{
강유전체 $\mathrm{BiFeO}_{3}$ 가 증착된 $\mathrm{TiO}_{2}$ 전극을 이용한 염료감응형 태양전지의 효율 향상
}

\author{
주호용 ${ }^{1}$, 홍수봉 ${ }^{1}$, 이호상 ${ }^{1}$, 전지훈 $^{2}$, 박배호 $^{2}$, 홍성철 $^{1}$, 최택집 ${ }^{1, a}$ \\ 1 세종대학교 나노신소재공학과 \\ 2 건국대학교 물리학과
}

\section{Ferroelectric $\mathrm{BiFeO}_{3}-$ coated $\mathrm{TiO}_{2}$ Electrodes for Enhanced Photovoltaic Properties of Dye-sensitized Solar Cells}

\author{
Ho-Yong Joo ${ }^{1}$, Su Bong Hong ${ }^{1}$, Hosang Lee ${ }^{1}$, Ji Hoon Jeon ${ }^{2}$, Bae Ho Park ${ }^{2}$, \\ Sung Chul Hong ${ }^{1}$, and Taekjib Choi ${ }^{1, a}$ \\ ${ }^{1}$ Department of Nanotechnology and Advanced Materials Engineering, Sejong University, Seoul 143-747, Korea \\ ${ }^{2}$ Department of Physics, Konkuk University, Seoul 143-701, Korea
}

(Received January 23, 2013; Accepted February 12, 2013)

\begin{abstract}
Dye-sensitized solar cells (DSSCs) based on titanium dioxide $\left(\mathrm{TiO}_{2}\right)$ have been extensively studied because of their promising low-cost alternatives to conventional semiconductor based solar cells. DSSCs consist of molecular dye at the interface between a liquid electrolyte and a mesoporous wide-bandgap semiconductor oxide. Most efforts for high conversion efficiencies have focused on dye and liquid electrolytes. However, interface engineering between dye and electrode is also important to reduce recombination and improve efficiency. In this work, for interface engineering, we deposited semiconducting ferroelectric $\mathrm{BiFeO}_{3}$ with bandgap of $2.8 \mathrm{eV}$ on $\mathrm{TiO}_{2}$ nanoparticles and nanotubes. Photovoltaic properties of DSSCs were characterized as a function of thickness of $\mathrm{BiFeO}_{3}$. We showed that ferroelectric $\mathrm{BiFeO}_{3}$-coated $\mathrm{TiO}_{2}$ electrodes enable to increase overall efficiency of DSSCs, which was associated with efficient electron transport due to internal electric field originating from electric polarization. It was suggested that engineering the dye- $\mathrm{TiO}_{2}$ interface using ferroelectric materials as inorganic modifiers can be key parameter for enhanced photovoltaic performance of the cell.
\end{abstract}

Keywords: Ferroelectrics, $\mathrm{BiFeO}_{3}, \mathrm{TiO}_{2}$, Photovoltaic effect, Interface engineering, Efficient electron transport, Dye-sensitized solar cells

\section{1. 서 론}

a. Corresponding author; tjchoi@sejong.ac.kr

Copyright (O2013 KIEEME. All rights reserved.

This is an Open-Access article distributed under the terms of the Creative Common Attribution Non-Commercial License (http://creativecommons.org/licenses/by-nc/3.0) which permits unrestricted non-commercial use, distribution, and reproduction in any medium, provided the original work is properly cited.
염료감응형 태양전지 (dye-sensitized solar cells, $\mathrm{DSSCS}$ )는 고효율의 광전기화학적 태양전지로 기존의 반도체 기반 태양전지에 비해 낮은 제조 단가와 쉬운 공정과 응용분야의 다양성으로 인해 많은 연구가 진 행되고 있다 [1-3]. 염료감응형 태양전지는 주로 나노 다공성의 산화물 반도체 $\mathrm{TiO}_{2}$ 광전극, 광감응형 염료, 
전해질, 상대전극으로 구성된다. 전지에 태양광이 조 사되면, 산화물 반도체 표면에 흡착된 염료에서 태양 광을 흡수하여 전자를 발생하고 이 전자는 산화물 반 도체의 전도대로 전달되어 상대전극까지 이동하며, 전해질의 산화 환원 반응을 통해 재결합이 이루어진 다 [3].

현재 염료감응형 태양전지의 효율 향상을 위한 다 양한 방법들이 제시되고 있다 [4-7]. 주로 산화물 반 도체, 염료, 전해질, 상대전극 등 각각의 대상 신물질 연구가 이루어지고 있다. 산화물 반도체 관련 연구에 서는 광전극의 표면 개질과 나노구조체를 이용하여 광전극의 비표면적을 높여 염료 흡착량을 증가시켜 에너지 변화 효율을 향상시키고자 하는 방법이 최근 보고되고 있다 $[5,6]$. 한편 이러한 연구에서는 산화물 반도체와 흡착된 염료 사이에서의 전자의 효과적인 전달 과정은 효율 향상에 중요한 요소가 된다 [7]. 따 라서 산화물 반도체 $\mathrm{TiO}_{2}$ 와 염료 계면의 특성 변화는 염료감응형 태양전지의 광전류 특성 및 효율에 큰 영 향을 미칠 것이다.

본 연구에서는 산화물 반도체 산화티타늄 나노분말 $\left(\mathrm{TiO}_{2}\right.$ nanoparticles, $\left.\mathrm{TNP}\right)$ 과 나노튜브 $\left(\mathrm{TiO}_{2}\right.$ nanotubes, TNT) 위에 펄스 레이저 증착법 (pulsed laser deposition, $\mathrm{PLD}$ )을 이용하여 강유전성 반도체 $\mathrm{BiFeO}_{3}(\mathrm{BFO})$ 박막 을 성장하여 산화물 반도체와 염료 계면을 변화시켰 다. 강유전체 $\mathrm{BiFeO}_{3}$ 는 $2.8 \mathrm{eV}$ 의 밴드갭을 갖는 산화 물 반도체로 가시광선을 흡수하여 전자와 공공을 생 성할 수 있으며, 자발 전기 분극을 가지고 있기 때문 에 내부 전기장에 의한 광전기 효과를 보인다 [8]. 따 라서 광전극 $\mathrm{TiO}_{2}$ 와 염료 사이에 강유전체 박막을 도 입하여 가시광선 빛 흡수와 강유전체 박막의 내부 전 기장을 통해 효과적인 전자 전달을 유도하여 광효율 을 개선하고자 하였다. 또한 증착시간을 조절하여 $\mathrm{BFO}$ 의 박막 두께에 따른 광전류특성과 효율을 비교 분석하였다.

\section{2. 실험 방법}

\section{$2.1 \mathrm{BiFeO}_{3}$ 가 코팅된 $\mathrm{TiO}_{2}$ 광전극 제작}

$\mathrm{TiO}_{2}$ 광전극은 나노분말과 나노튜브를 이용하여 제조하였다. $\mathrm{TiO}_{2}$ 나노페이스트는 평균 입자 크기가 $20 \mathrm{~nm}$ 인 나노분말을 이용하였다. $\mathrm{TiO}_{2}$ 나노튜브는 양극산화법을 이용하여 제조하였다 [9]. 양질의 $\mathrm{TiO}_{2}$

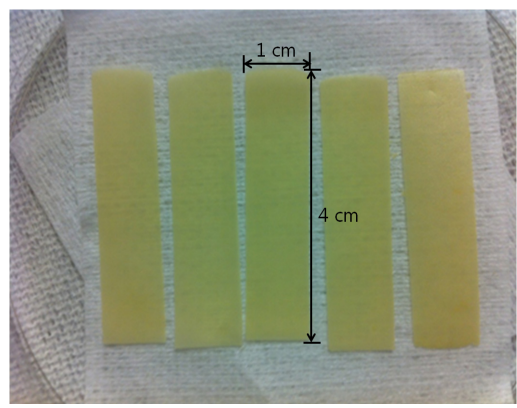

Fig. 1. Photography of $\mathrm{TiO}_{2}$ nanotube (TNT) membrane fabricated by anodizing method.

나노튜브를 제조하기 위하여 총 3 번의 양극산화를 진 행하였고, 모든 양극산화는 $15^{\circ} \mathrm{C}, 60 \mathrm{~V}$ 에서 이루어졌 으며, 전해질로는 $0.2 \mathrm{wt} \%$ 플루오르화암모늄과 2 vol.\% 탈이온증류수 (deionized water)를 함유한 에틸 렌클리콜 $(99.5 \%)$ 사용하였다. 전해질에 담가져 있는 양극에 $\mathrm{Ti}$ 기판, 음극에 $\mathrm{Pt}$ 기판을 연결한 후 1 시간 동안 1 차 산화를 진행하였다. $\mathrm{Ti}$ 기판에 생긴 1 차 산 화막은 튜브의 모양이 매우 불규칙적이어서 에탄올과 탈이온 증류수에서 40 분 간 초음파 세척을 진행하여 물리적으로 나노튜브를 제거해 주었다. 3 시간 동안 2 차 산화를 진행한 후 $500^{\circ} \mathrm{C}$ 에서 1 시간 동안 열처리를 통해 anatase상의 결정구조를 갖는 TNT 산화막을 제조하였다. TNT 산화막을 $\mathrm{Ti}$ 기판으로부터 분리하 기 위해 3 차 산화를 15 분 간 진행한 후 과산화수소 (33\%)에 10 분 동안 담지하였다.

그림 1 은 제조된 TNT 산화막의 광학 이미지이다. 일정한 크기의 TNT 산화막을 얻을 수 있었다. 광전 극은 전도성 유리 기판 $\mathrm{SnO}_{2}: \mathrm{F} \quad$ (FTO, $\mathrm{TEC} 8$, Pilkington, $8 \Omega / \square$, 유리두께 : $2.3 \mathrm{~mm}$ ) 위에 TNP와 TNT를 코팅하여 제조하였다. TNP는 doctor-blade 방법으로 코팅하였다. $\mathrm{TiO}_{2}$ 총 두께를 균일하게 하기 위해 TNT를 이용한 광전극은 TNP을 페이스트 형태 로 하여 $5 \mu \mathrm{m}$ 로 코팅하였고, TNP만을 이용한 전극 은 $24 \mu \mathrm{m}$ 로 코팅하였다. TNP의 소결을 위해 $500^{\circ} \mathrm{C}$ 에서 1시간 동안 열처리하였다. TNP와 TNT를 이용 한 광전극 위에 $\mathrm{PLD}$ 를 이용하여 강유전체 $\mathrm{BFO}$ 박막 을 증착하였다. 박막 두께 조절을 위하여 증착 시간 은 15분 (BFO15), 30분 (BFO30), 45분 (BFO45), 60 분 $(\mathrm{BFO} 60)$ 으로 변화시켰다. 15 분 증착된 박막 두께 는 약 $100 \mathrm{~nm}$ 이다. PLD ( $\mathrm{KrF}$ excimer laser)는 레이 저 파워는 $200 \mathrm{~mJ}$, 증착 온도는 $500^{\circ} \mathrm{C}, 20 \mathrm{mTorr}$ 의 
산소 분위기에서 이루어졌다. 박막의 결정성의 향상 을 위해 산소 분위기에서 $550^{\circ} \mathrm{C}$ 에서 30 분 간 후열처 리를 진행하였다. 압전주사탐침현미경 (piezoresponse force microscopy, $\mathrm{PFM}$ )을 이용하여 증착된 $\mathrm{BFO}$ 의 박막의 강유전성을 평가하였다. $\mathrm{BFO}$ 가 증착된 $\mathrm{TNP}$ 와 TNT 광전극의 결정구조 분석과 미세 표면 구조 분석은 $\mathrm{X}$-선 회절법 (X-ray diffraction, $\mathrm{XRD}$ )과 전 계방출 주사전자현미경 (field emission-scanning electron microscopy, $\mathrm{FE}-\mathrm{SEM}$ )을 각각 이용하였다.

\section{2 염료감응형 태양전지 제조 및 광효율 특성 평가}

그림 2는 $\mathrm{TNP}$ 와 $\mathrm{TNT}$ 를 이용한 광전극 위에 강유 전체 $\mathrm{BFO}$ 박막이 도입된 염료감응형 태양전지의 모 식도와 제작된 단위 셀을 보여주고 있다.

\begin{tabular}{|c|}
\hline (a) FTO glass \\
\hline Pt \\
\hline Dye \& electrolyte \\
\hline BFO \\
\hline TNP or TNT \\
\hline FTO glass \\
\hline
\end{tabular}

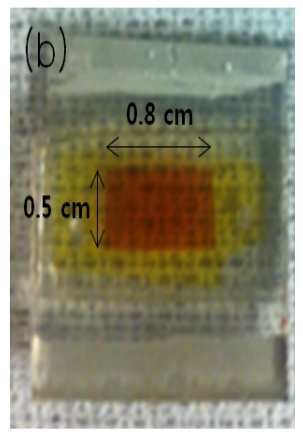

Fig. 2. (a) The schematic diagram and (b) photography of dye-sensitized solar cell (DSSC) with ferroelectric $\mathrm{BiFeO}_{3}$-coated $\mathrm{TiO}_{2}$ nanoparticles (TNP) and nanotubes (TNT) as a photoelectrode.

염료 담지는 $0.5 \mathrm{mM}$ 의 에탄올이 첨가된 $\mathrm{N}-719$ (Solaronix)을 이용하여 $60^{\circ} \mathrm{C}$ 에서 3시간 동안 이루어 졌다. $\mathrm{Pt}$ 상대전극은 $7 \mathrm{mM}$ 의 육염화백금산을 스핀 코팅한 후 $400^{\circ} \mathrm{C}$ 에서 20 분 간 열처리하여 제조하였 다. 상대전극과 광전극을 갖는 두 유리 기판 사이에 전해질을 주입하고 설린 (Solaronix 1170-25)을 사용 하여 밀봉하여 염료감응형 태양전지 단위 셀을 제작 하였다. 단위 셀의 총면적은 $40 \mathrm{~mm}^{2}$ 로 하였다. 제작 된 단위 셀은 Keithley 2400 electrometer와 solar simulator system (1.5 air mass filter, 1 sun)을 이용 하여 개방전압 $\left(V_{o c}\right)$, 광전류 밀도 $\left(J_{s c}\right)$, 충전인자 (fill factor, $\mathrm{FF})$, 에너지 변환효율 ( $\mathrm{g})$ 을 측정하였다.

\section{3. 결과 및 고찰}

그림 3 은 $\mathrm{TNP}$ 광전극과 그 위에 $\mathrm{BFO}$ 가 15 분 (BFO15)과 45분 (BFO45) 증착된 광전극의 표면 $\mathrm{SEM}$ 이미지이다. $\mathrm{BFO}$ 의 두께는 각각 약 $100 \mathrm{~nm}$ 와 약 $300 \mathrm{~nm}$ 정도이다. $\mathrm{TNP}$ 광전극은 균질한 나노다 공성 표면형상을 보이며, $\mathrm{BFO}$ 증착 시간이 증가함에 따라 다공성 형상에서 결정립을 갖는 표면으로 변해 가는 것을 알 수 있다. 이러한 표면 형상 변화는 광 전극의 비표면적과 염료 흡착량에 영향을 줄 것이다. 또한 광전극과 염료사이의 계면 특성 변화에 따른 전 자 전달에 영향을 주게 될 것이다. 이에 따라 광전류 -전압 특성 및 광효율 변화가 예상된다.
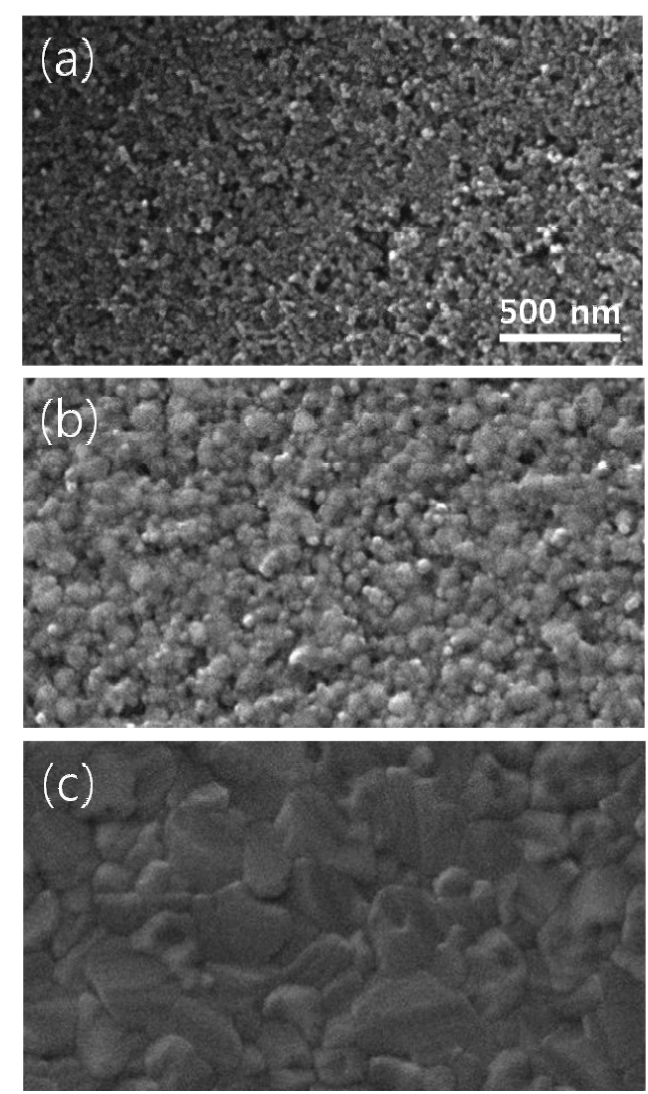

Fig. 3. SEM images of the top view for (a) TNP, (b) BFO15/TNP and (c) BFO45/TNP.

그림 4는 $\mathrm{TNT}$ 광전극과 $\mathrm{BFO}$ 가 45 분 증착된 광전 극 $(\mathrm{BFO} 45 / \mathrm{TNT})$ 의 표면과 단면 $\mathrm{SEM}$ 이미지이다. TNT 광전극은 기공크기가 $100 \sim 120 \mathrm{~nm}$ 범위를 갖 


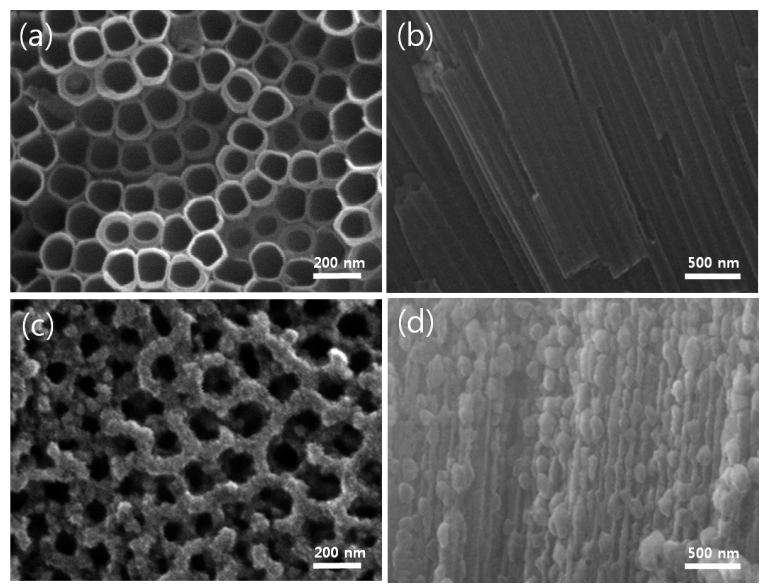

Fig. 4. Plane-view and cross $^{-}$sectional SEM images of (a,b) TNT and (c,d) BFO45/TNT.

는 매끄럽고 균일한 튜브형태를 보이고 있다. $\mathrm{BFO} 45 / \mathrm{TNT}$ 광전극의 표면은 $\mathrm{BFO}$ 가 나노튜브의 기 공을 따라 증착되어 다공성 형상을 보인다. 하지만 단면 이미지에서 보이는 바와 같이 $\mathrm{BFO}$ 가 나노튜브 의 안쪽에 구슬사슬 형태로 증착되어 기공을 채우고 있다. 또한 $\mathrm{BFO}$ 증착시간이 증가함에 따라 아래쪽에 서 위쪽으로 조밀하게 증착되었다. 이러한 증착형태 는 초기의 $\mathrm{TNT}$ 광전극의 비표면적이 $\mathrm{BFO}$ 증착시간 이 늘어남에 따라 점차적으로 감소되어 염료가 튜브 안쪽까지 담지 되는 것을 방해할 것으로 예상된다.

그림 5 는 $\mathrm{TNP}$ 와 $\mathrm{TNT}$ 광전극 위에 증착된 $\mathrm{BFO}$ 박막의 증착시간에 따른 $\mathrm{X}$-선 회절 패턴을 보여주고 있다. $\mathrm{TNP}$ 와 $\mathrm{TNT}$ 모두 $\mathrm{TiO}_{2}$ 의 anatase 결정구조를 보이고 있으며, $\mathrm{BFO}$ 박막은 다결정형태로 성장된 것 을 알 수 있다. 한편, $\mathrm{BFO}$ 박막은 증착두께가 증가함 에 따라 (110) 우선 방향으로 성장하였다. $\mathrm{BFO}$ 는 준 입방체 결정구조를 갖고, 자발전기분극의 주방향은 [111]으로 8가지의 방향성을 가질 수 있기 때문에 $71^{\circ}, 107^{\circ}, 180^{\circ}$ 도메인 구역벽 (domain wall)을 갖는 복잡한 도메인구조를 보인다 [10]. 따라서 광전극 위 에 증착된 $\mathrm{BFO}$ 의 도메인 구조는 자발전기분극 방향 과 표면전하의 극성을 결정한다. 이러한 자발분극에 의한 표면전하는 염료와 광전극 계면에 내부전기장을 유도한다. $\mathrm{TNP}$ 와 $\mathrm{TNT}$ 광전극과 염료 계면의 효과 적인 전자 전달을 위해서는 $\mathrm{BFO}$ 박막의 전기분극은 위쪽으로 향해 표면전하가 양전하로 대전되어서 계면 에서 발생하는 내부 전기장에 의해 염료에서 발생한
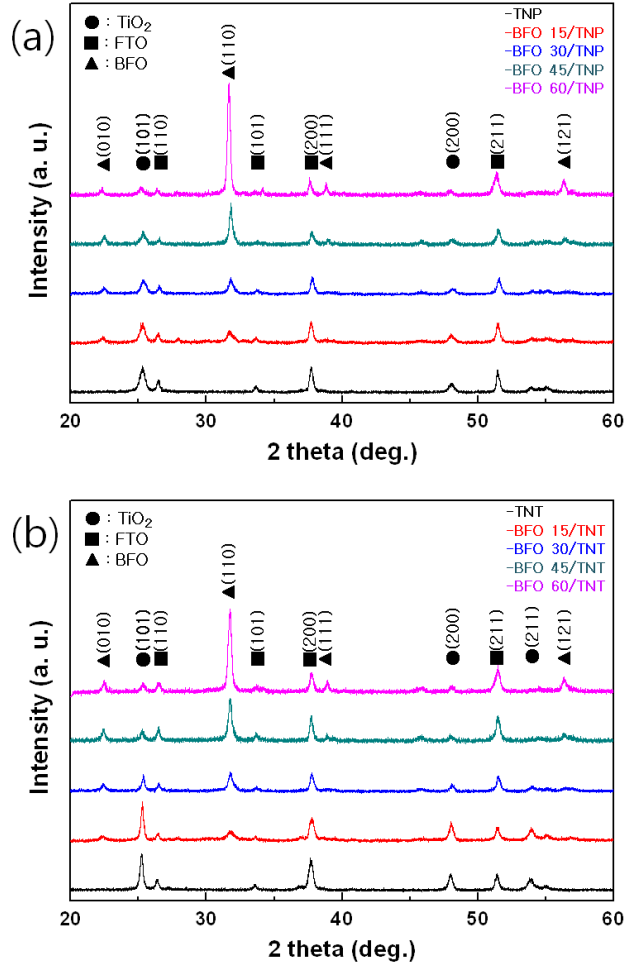

Fig. 5. X-ray diffraction patterns for (a) BFO/TNP (b) $\mathrm{BFO} / \mathrm{TNT}$ as a function of BFO deposition time.

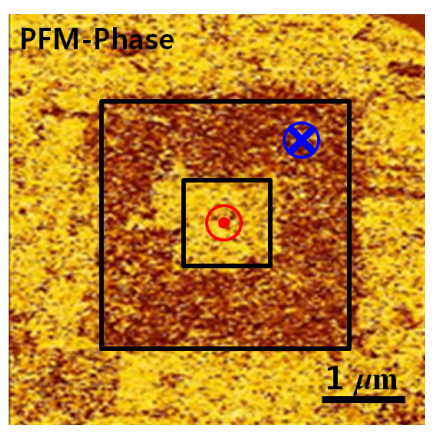

Fig. 6. PFM-phase image of BFO45/TNT sample.

여기전자가 효과적으로 광전극의 전도대로 주입되어 야 한다. $\mathrm{PFM}$ 을 이용하여 $\mathrm{BFO}$ 의 강유전성 특성과 전기분극 방향을 확인하였다.

그림 6은 $\mathrm{BFO} 45 / \mathrm{TNT}$ 광전극의 $\mathrm{PFM}-$ phase 이미 지이다. Phase 이미지의 명암은 전기분극 방향을 나 타낸다. 밝은 부분은 전기분극 방향이 표면 위쪽으로 향하고 있는 영역이고 어두운 부분은 아래쪽을 향하 

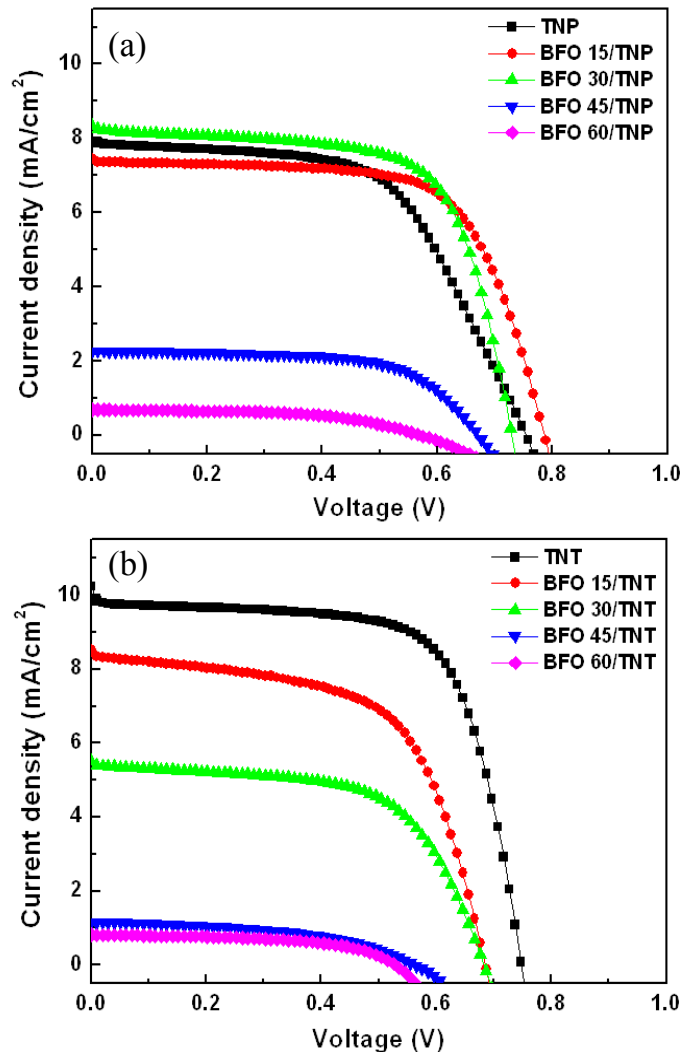

Fig. 7. Photocurrent density-voltage $(J-V)$ characteristics of DSSCs consisted of (a) BFO/TNPs and BFO/TNTs with various $\mathrm{BFO}$ deposition times.

는 영역에 해당한다. $\mathrm{PFM}$ 의 탐침에 $+90 \mathrm{~V}$ 의 전압을 인가하여 일정 영역을 전기분극을 아래쪽으로 편극한 후 그 안쪽에 $-90 \mathrm{~V}$ 로 다시 전기분극을 위쪽으로 반 전시켰다. 그림 6 에서 보이는 바와 같이 인가전압 극 성에 따라 분극반전에 의한 명암반전을 관찰 할 수 있다. 이것은 $\mathrm{BFO}$ 박막의 강유전성을 의미한다. 또한 광전극 위에 증착된 $\mathrm{BFO}$ 박막은 대부분 전기분극 뱡 향이 위쪽을 향하고 이로 인해 박막 표면은 양전하로 대전된다. 따라서 $\mathrm{BFO}$ 의 표면 양전하는 광전극과 염 료 계면에 내부 전기장을 유도하고 전기장이 염료의 여기전자 주입에 바람직한 방향으로 향하여 이에 따 른 광효율의 향상을 예상할 수 있다.

그림 7은 $\mathrm{BFO}$ 가 코팅된 $\mathrm{TNP}$ 와 $\mathrm{TNT}$ 광전극 기반 으로 한 단위 셀의 광전류밀도 $(J)$ 와 전압 $(V)$ 그래 프이다. $\mathrm{BFO}$ 증착시간에 따른 염료감응형 태양전지 의 광전기 특성 결과를 표 1 에 요약하였다.
Table 1. Photovoltaic parameters of DSSCs fabricated with BFO/TNPs and BFO/TNTs.

\begin{tabular}{ccccc}
\hline sample & $\begin{array}{c}\mathrm{V}_{\mathrm{oc}} \\
(\mathrm{mV})\end{array}$ & $\begin{array}{c}\mathrm{J}_{\mathrm{sc}} \\
\left(\mathrm{mA} / \mathrm{cm}^{2}\right)\end{array}$ & $\begin{array}{c}\mathrm{FF} \\
(\%)\end{array}$ & $\begin{array}{c}\mathrm{PCE} \\
(\%)\end{array}$ \\
\hline \hline TNP & 757.6 & 7.9 & 57.8 & 3.5 \\
BFO15/TNP & 787.9 & 7.4 & 66.8 & 3.9 \\
BFO30/TNP & 727.2 & 8.4 & 67.0 & 4.1 \\
BFO45/TNP & 666.6 & 2.3 & 63.8 & 0.9 \\
BFO60/TNP & 565.6 & 0.68 & 54.4 & 0.2 \\
\hline TNT & 747.5 & 10.2 & 66.5 & 5.1 \\
BFO15/TNT & 686.8 & 8.5 & 59.3 & 3.5 \\
BFO30/TNT & 686.8 & 5.5 & 59.8 & 2.3 \\
BFO45/TNT & 565.5 & 1.2 & 47.3 & 0.3 \\
BFO60/TNT & 525.2 & 0.81 & 55.3 & 0.2 \\
\hline
\end{tabular}

TNP와 TNT 광전극으로만 구성된 단위 셀의 광전기 특성을 비교해 보면 TNT 기반 단위 셀의 광전류밀 도가 같은 두께의 $\mathrm{TNP}$ 기반 단위 셀보다 큰 값을 보 이고 있다. 이것은 광전극의 나노튜브 구조로 인한 비표면적 향상과 염료 흡착량의 증가로 인한 것으로 충전인자와 광효율도 크게 향상되었다. 한편 $\mathrm{BFO}$ 가 코팅된 $\mathrm{TNP}$ 기반 단위 셀의 경우에 $\mathrm{BFO}$ 의 증착시 간 또는 박막두께가 증가함에 따라 개방전압 또는 광 전류 밀도 및 충전인자 값도 같이 증가하여 총 광변 화 효율이 크게 개선되었다. $\mathrm{BFO} 30 / \mathrm{TNP}$ 기반 단위 셀이 $8.4 \mathrm{~mA} / \mathrm{cm}^{2}$ 의 광전류 밀도와 $4.1 \%$ 의 광효율로 가장 높은 값을 보이고 있다. 하지만 $\mathrm{BFO}$ 증착시간 이 45분 이상이 되면, 앞선 광전극 표면의 SEM이미 지에서 확인된 바와 같이 다공성 표면에서 결정상 표 면으로 변하여 광전극의 비표면적 감소된다. 따라서 이에 따른 염료 흡착량 감소로 인해 광전류 밀도가 크게 감소하였다. 또한, 이것은 $\mathrm{BFO}$ 박막의 두께가 $300 \mathrm{~nm}$ 이상이 되면서 $\mathrm{BFO}$ 박막의 저항값이 크게 증가하여 단위 셀의 총 저항값의 증가로 인한 광효율 손실 때문으로 판단된다. $\mathrm{BFO} / \mathrm{TNT}$ 기반의 단위 셀 의 경우 초기 높은 광전극의 비표면적에 의한 높은 광효율에도 불구하고 $\mathrm{BFO}$ 증착시간 (박막두께) 증가 에 따라 총 광효율이 계속적으로 감소하였다. 이것은 $\mathrm{BFO}$ 증착시간이 늘어남에 따라 나노튜브의 기공을 $\mathrm{BFO}$ 로 채워지면서 전반적인 광전극 비표면적과 염료 흡착량 감소 때문으로 판단된다. 하지만 $\mathrm{BFO} 15 / \mathrm{TNT}$ 의 경우는 $\mathrm{TNP}$ 기반 단위 셀보다 높은 광전류 밀도 값을 보였다. 이것은 TNT 광전극과 염료 계면에서의 $\mathrm{BFO}$ 박막의 전기분극에 의한 내부전기장이 발생하여 전자 주입과 전자 전달이 효과적으로 이루어졌기 때 


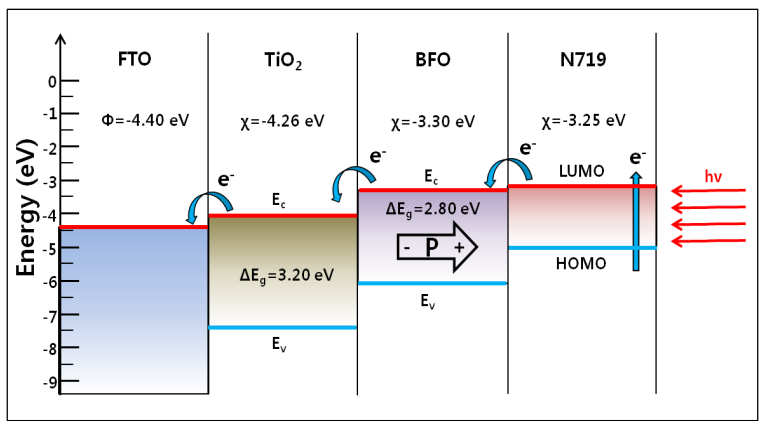

Fig. 8. Energy levels of the components of DSSCs with $\mathrm{BFO} / \mathrm{TiO}_{2} / \mathrm{FTO}$ structure.

문으로 생각된다.

그림 8은 TNP와 TNT 광전극과 N719 계면 사이 에 강유전체 $\mathrm{BFO}$ 박막이 도입된 염료감응형 태양전 지 단위 셀의 에너지 밴드 다이아그램이다 [11,12]. 이를 통해 $\mathrm{BFO}$ 박막의 밴드갭은 $2.8 \mathrm{eV}$ 로 가시광선 흡수와 전기분극으로 인한 염료의 여기전자가 광전극 으로 효과적으로 주입 및 전달될 수 있음을 알 수 있 다. 하지만 단위 셀의 총 태양에너지 변화 효율의 향 상을 위해서는 $\mathrm{BFO}$ 박막 두께와 광전극의 표면 형상 의 최적화가 요구된다.

\section{4. 결 론}

본 연구에서는 염료감응형 태양전지에 $\mathrm{TiO}_{2}$ 나노구 조체 기반 광전극과 염료 계면에 강유전체 $\mathrm{BFO}$ 박막 을 도입하여 광효율을 개선하고자 하였다. $\mathrm{BFO}$ 박막 의 증착시간을 변화시켜 광전극의 표면형상과 단위 셀의 광전기 특성을 비교하였다. TNT 광전극을 사용 한 단위 셀은 광전극의 비표면적의 증가로 인해 $\mathrm{TNP}$ 기반 단위 셀보다 우수한 광전기 특성을 보였다.

$\mathrm{BFO}$ 가 코팅된 광전극의 경우는 $\mathrm{TNP}$ 기반 단위 셀에서 $\mathrm{BFO}$ 박막의 전기분극으로 인한 광전극과 염 료 계면에 내부 전기장을 유도하여 효과적인 전하 주 입과 전달로 광효율 향상을 관찰하였고, TNT 기반
단위 셀의 경우에서는 $\mathrm{BFO}$ 박막이 나노튜브의 기공 을 채워 오히려 기공을 막아 광전극의 비표면적 감소 로 인해 광효율 감소가 발생하였다.

따라서 광전극과 염료계면 특성과 광전극의 표면 형상은 염료감응형 태양전지의 광전기 특성에 큰 영 향을 미치고 광효율 향상을 위해 $\mathrm{BFO}$ 박막의 두께의 최적화가 이루어져야 하겠다.

\section{감사의 글}

이 논문은 2011년도 세종대학교 교내 연구비 지원 을 받아 수행된 연구임.

\section{REFERENCES}

[1] A. Hagfeldt, G. Boschloo, L. C. Sun, L. Kloo, and H. Pettersson, Chem. Rev., 110, 6595 (2010).

[2] M. Grätzel, Acc. Chem. Res., 42, 1788 (2009).

[3] M. K. Nazeeruddin, A. Kay, I. Rodicio, R. HumphryBaker, E. Mueller, P. Liska, N. Vlachopoulos, and M. Grätzel, J. Am. Chem. Soc., 115, 6382 (1993).

[4] J. K. Koh, J. Kim, B. Kim, J. H. Kim, and E. Kim, Adv. Mater., 23, 1641 (2011).

[5] Y. Meidan, X. Xukai, L. Changjian, and L. Zhiqun, Nano Lett., 11, 3214 (2011).

[6] J. Choi, S. H. Park, Y. S. Kwon, J. Lim, I. Y. Song, and T. Park, Chem. Commun., 48, 8748 (2012).

[7] J. Bisquert, ChemPhysChem, 12, 1633 (2011).

[8] T. Choi, S. Lee, Y. J. Choi, V. Kiryukhin, and S. W. Cheong, Science, 324, 63 (2009).

[9] J. Wang and Z. Lin, Chem. Mater., 22, 579 (2010).

[10] G. Catalan and J. F. Scott, Adv. Mater., 21, 2463 (2009).

[11] J. Chung, J. Myoung, J. Oh, and S. Lim, J. Phys. Chem. Solids, 73, 535 (2012).

[12] O. Tonomura, T. Sekiguchi, N. Inada, T. Hamada, H. Miki, and K. Torii, J. Electrochem. Soc., 159, G1 (2012). 